\title{
Selected issues of waste landfilling in the Polish legislation
}

\author{
http://dx.doi.org/10.12775/PYEL.2012.004
}

Firstly, the issue of waste landfill is regulated in the Act on Waste of 27 April $2001^{1}$. Article 3(2)(16) defines the term , a waste landfill'. It is a built structure designed to landfill waste. The legislator, however, does not provide a definition of 'waste landfilling'. From other definitions we may deduce e.g. that waste landfilling at waste landfills is not treated as organic recycling ${ }^{2}$.

According to article 7(3) of the Act on Waste, the waste which cannot be recovered shall be disposed of in such a way that only the waste disposal of which in another way was impossible for technological reasons and/or unreasonable due to ecological or economic reasons would be landfilled. The fact that the legislator used the inclusive or (,and/or') means that waste may

* Ph.D. in Law, European School of Law and Administration in Warsaw (assistant professor), K. Szuma, H. Zambrowicz-Rybarczyk Office of Legal Counsels in Poznań; Studio Legale Dr Karolina Szuma in Poznań.

1 Journal of Laws of 2010, No 185, item 1243 with amendments, consolidated version, further referred to as the Act on Waste.

2 This term is defined in article 3(2)(15) of the Act on Waste., Organic recycling shall mean aerobic processing, including composting, or anaerobic processing of biodegradable waste under controlled conditions with the use of microorganisms, to produce organic matter or methane; deposition at a waste landfill shall not be regarded as organic recycling'. 


\section{Karolina Szuma}

also be landfilled when it is economically (or ecologically) unreasonable to dispose of it, but it is in fact technologically possible ${ }^{3}$. Besides, pursuant to the provisions set out in article 9(6)(3) of the Act on Waste, it is prohibited to collect and process e.g. the remainder of sorted communal waste which is to be landfilled outside the region of communal waste management, where it had been produced.

The judicial practice clearly says that: When we take into account the principle of proximity, we may point one place for recovery and disposal of waste. If one landfill offers significantly better conditions than the others from the environmental protection perspective the competent authority, when pointing a landfill the one which is significantly better than the others in the permits, does not violate the law, but in fact is obliged to do so' ${ }^{4}$. The doctrine, on the other hand, says that a commune (gmina) may not leave the choice of a waste landfill from among those listed in the regional waste management plan up to entrepreneurs who apply for a permit to carry out the activity of communal waste collection. The commune when carrying out its tasks related to the specification of waste landfills is bound by the regional waste management plan ${ }^{5}$.

The important issue is also the responsibility of a waste holder, i.e. if a waste holder, including also a waste producer, transfers waste to another waste holder who has a permit for landfilling waste in a rock mass, including underground mining excavations, the responsibility for operations covered by this permit is transferred to the subsequent waste holder (article 25(3) of the Act on Waste).

In article 29(2) the legislator points out that the competent authority refuses to grant a permit for the operations in the scope of the landfill of waste, if the manager of a waste landfill does not have a certificate of qualifications in waste management. The refusal to grant a permit is given by way of an administrative decision, which is a constrained decision. It means that if the authority ascertains given circumstances, it must (not may) refuse to grant a permit.

3 The same, see also W. Radecki, Komentarz do art.7 ustawy o odpadach, electronic publishing LEX.

4 Judgement of the Supreme Administrative Court [Naczelny Sąd Administracyjny] in Warsaw of 16 April 2008, II OSK 140/08.

5 M. Sieradzka, Gloss to the judgement of the Supreme Court of 3 March 2010, III SK 37/09, Lex no 131303/6. 
The Polish law also provides for a decision which orders a waste holder to remove waste from sites not indented for waste landfilling. Pursuant to article 34 of the Act on Waste, the head of a commune (wojt), the mayor of a town (burmistrz) or the mayor of a city (prezydent miasta) may order the waste holder to remove waste from sites not intended for waste landfilling or storage, indicating the manner in which this decision is to be implemented. The decision is made ex officio. We must remember that whenever a competent authority ascertains that a waste holder deposits waste in a site which is not a waste landfill, this authority is obliged, under article 34(1) of the Act on Waste, to order the waste holder to remove waste from a site not intended for waste landfilling or storage ${ }^{6}$.

There are following types of waste landfills: hazardous waste landfills, inert waste landfills, non-hazardous and non-inert waste landfills ${ }^{7}$. The underground storage of waste is regulated by the Act of 9 June 2011 Geological and Mining Law ${ }^{8}$.

The Regulation of the Minister of the Environment of 24 March 2003 on detailed requirements concerning the localisation, construction, operation, and closure of particular types of landfills ${ }^{9}$ must also be taken into account.

According to article 3(1) of the above mentioned Regulation, hazardous waste landfills, non-hazardous and non-inert waste landfills may not be located:

1) in the supply zones of main and utility groundwater basins (main groundwater basin, utility groundwater basin);

2) within the buffer zones of national parks and nature reserves;

3) within the protection forests;

4) in the river valleys, near the inland water reservoirs, in the spring, boggy, waterlogged areas, within the lake basins and their edge zones, in the area of direct or potential flood risk within the meaning of the Water Act provisions;

5 ) in the zones of landslides and land subsidence, including but not limited to those resulting from karst formations, and in the avalanche risk areas;

6 See also Judgement by the Supreme Administrative Court [Naczelny Sad Administracyjny] in Warsaw of 20 July 2011, II OSK 1162/10.

7 See article 50(1) of the Act on Waste.

8 Journal of Laws of 2011, No 163, item 981.

9 Journal of Laws of 2003, No 61, item 549. 


\section{Karolina Szuma}

6) in the areas of inclination exceeding $10^{\circ}$;

7 ) in the areas with glaciotectonic and tectonic features, cut with faults or fissures, or cracked;

8 ) in the areas with the outcrops of solid, porous, karsted and cavernous rocks;

9) on the soil of category I-II;

10) in the areas potentially affected by surface deformation caused by mining damage;

11) within the protected spa areas;

12) in the mining areas created for extracting curative minerals;

13) in the areas specified in the separate provisions of law.

As for inert waste landfills, they may not be located in the areas referred to in points $1-6$ and 13 .

The minimum distance from a hazardous waste landfill or from nonhazardous or non-inert waste landfills to residential buildings, boarding house buildings and public utilities, as defined in the Construction Law, measured from the edge of a landfill, is determined in compliance with the report on the environmental impact of a landfill.

The above requirements are also applied in the case of the expansion of waste landfills.

Pursuant to article 4(1) of the Regulation, in the area of an intended waste landfill and in its proximity hydrological and geological research is to be carried out. The results of the above mentioned research, which is carried out in compliance with the requirements set out in the provisions regarding the project of geological works, are to be attached to the petition for a zoning approval for a waste landfill together with the prepared geological and engineering documentation, and the prepared hydrological documentation, both compatible with the requirements specified in the provisions regarding geological, engineering, and hydrological documentation.

Waste landfills should be located at a site which provides natural geological barrier sealing the ground and side walls. Hazardous waste landfills, non-hazardous and non-inert waste landfills are equipped with a leachate water drainage system, which is developed in order to provide failproof operation throughout the exploitation of the landfill and at least 30 years after its closure. If a part of a non-hazardous and non-inert waste landfill is separated for landfilling hazardous waste, such a part must be equipped with a separate drainage system. 
The part for a hazardous waste landfill or a non-hazardous and a noninert waste landfill must be created in a way preventing hazardous waste from contact with other waste.

Then, pursuant to article 8(1) of the Regulation, hazardous waste landfills, non-hazardous and non-inert waste landfills are surrounded by an external system of drainage ditches to prevent the inlet of surface water and underground water to a waste landfill.

Biodegradable waste landfills are equipped with a facility for landfill gas offtake. Moreover, a waste landfill must be surrounded by a lane of trees and bushes in order to minimize the inconvenience and risk arising from the waste landfill emitting odours and dust, waste being carried by the wind, road noise and traffic, animal influence, formation of aerosols and fires. The minimum width of the greenery is 10 metres. For a waste landfill intended exclusively for non-communal waste, the necessity to create the greenery lane, its width and location depends on the nuisance and location of a landfill.

Biodegradable waste landfills are equipped with a facility for washing and disinfecting the wheels of vehicles leaving the landfill. More rules are set out in the above mentioned Regulation.

Pursuant to article 51(1) of the Act on Waste, the authority competent to issue a zoning approval with regard to a waste landfill may make the issuance of such a decision conditional on the investor's submission of an expert study on the possibilities of waste recovery or disposal in a manner other than a landfill.

The legislator stipulated that the siting of a waste landfill in the vicinity of airfields requires consent from the aviation administration authorities, whereas siting in the vicinity of historic sites or within existing sites of archaeological excavations requires consent from the voivodeship heritage monuments protection officer (wojewódzki konserwator zabytków). The siting of a waste landfill within the coastal zone and sea ports and harbours requires consent of the director of the maritime office. Here it is worth noticing that if there is no comprehensive plan for future development for a given area, the siting of a waste landfill is determined by way of a location decision. If there is such a plan for a given area, then consent of the above mentioned authorities is required during the planning procedure ${ }^{10}$. The

10 See W. Radecki, Komentarz do art. 51 ustawy o odpadach, electronic publishing LEX. 


\section{Karolina Szuma}

authority competent to issue a zoning approval with regard to a waste landfill refuses to issue such a decision in the absence of the consent provided for hereinabove or where there is a technical, environmental and economic possibility of waste being recovered or disposed of without the construction of a waste landfill.

Pursuant to article 52(1) of the Act on Waste, an application for a permit for the construction of a waste landfill must also contain:

- the first and the family name and the place of residence, or the name and the seat of an applicant and an operator of a waste landfill if they are different entities, as well as the address of a waste landfill;

- types of waste intended to be deposited at a given waste landfill;

- expected annual and total amount of waste to be deposited and the capacity of a waste landfill;

- a description of the site of a waste landfill, in particular its geological and hydrogeological characteristics;

- a description of measures to prevent environmental pollution and to reduce the quantity of waste and its adverse effect on the environment;

- an operation, management and monitoring plan for a waste landfill;

- a plan for the closure of a waste landfill and after-care activities,

- measures to prevent accidents and to respond to them should they occur;

- skills of the personnel to be employed;

- proposed amount and form of securing claims.

The authority competent to issue a permit for the construction of a waste landfill in this permit sets out the requirements to ensure the protection of human life and health, environmental protection and the protection of justified interests of third parties. The requirements cover:

- the type of a waste landfill;

- technical conditions for a waste landfill;

- types of waste allowed to be deposited at a waste landfill;

- if a part of a landfill for non-hazardous waste has been separated to hold hazardous waste, types of hazardous waste allowed to be deposited in a separated part of a landfill for non-hazardous waste;

- annual and total quantity of waste authorised to be deposited at a landfill;

- a manner of a landfill operation;

- the target landfill ceiling (the maximum height) of deposit at a landfill; 
- a manner of leachate collection, cleaning and removal;

- a manner of landfill gas collection, cleaning and use or disposal;

- a manner, frequency and period of monitoring of a waste landfill;

- a manner of responding to accidents;

- a technical specification of the closure of a landfill;

- reclamation trends;

- an obligation to obtain an operating permit for a waste landfill;

- a specification of the amount and form of securing claims.

The authority competent to issue a permit for the construction of a waste landfill refuses to grant such a permit if the regional waste management plan does not provide for construction of a waste landfill.

Then, pursuant to article 53(1) the operating permit for a waste landfill may be granted after the instruction for waste landfill operations has been approved and after the voivodeship inspector for environmental protection has inspected the site.

An application for the approval of the instruction for waste landfill operations should contain:

- the first and last name and place of residence, or the name and seat of an applicant and an operator of a waste landfill if they are different entities, as well as the address of a waste landfill;

- the type of a waste landfill;

- if it is not a hazardous waste landfill, an indication whether any parts of it have been separated to hold specific types of hazardous waste;

- types of waste intended to be stored at a landfill;

- qualifications of a manager and personnel of a waste landfill;

- specification of technical equipment necessary to ensure proper functioning of a waste landfill;

- specification of control and measuring systems, along with a diagram representing the distribution of measuring points;

- the manner of depositing individual types of waste;

- the type and thickness of the insulating layer used;

- opening hours of a waste landfill;

- measures to prevent unauthorised persons' access to a waste landfill;

- procedures of accepting waste to a waste landfill;

- the manner and frequency of testing;

- the manner of keeping documentation regarding the operations of a waste landfill; 


\section{Karolina Szuma}

- an emergency plan, particularly in case of detection of any change in the quality of groundwaters caused by the emissions of substances from a waste landfill.

The instruction for waste landfill operations is approved by a decision of:

- the regional director for environmental protection - for projects and incidents in closed areas;

- the marshal of a voivodeship - for projects or installations referred to in article 378(2a) of the Act of 27 April 2001 - the Environmental Protection Act;

- the head of powiat (starosta) - for other projects.

By way of a decision, the authority refuses to approve the instruction for waste landfill operations when:

- the manager of a waste landfill does not have a certificate demonstrating his qualifications in the scope of waste management;

- the instruction includes provisions in contradiction with sanitary requirements, occupational health and safety requirements, fire protection requirements and those of environmental protection;

- the manner of operation is in contradiction with the terms of the decision setting out the conditions for land building up and development or those of the construction permit,

- the manner of operation might pose danger to human life and health or to the environment.

Moreover, with the consent of the party for which the decision approving the instruction for waste landfill operations has been issued, the authority competent to approve this decision is obliged to transfer the decision to another party provided that the party accepts all the conditions contained therein ${ }^{11}$.

The decision approving the instruction for waste landfill operations specifies:

- the type of a waste landfill;

- if it is necessary, the parts of a non-hazardous waste landfill which have been separated to hold specific types of hazardous waste;

- types of waste allowed to be stored at a waste landfill;

- technical equipment necessary for proper functioning of a waste landfill;

11 See more on this topic in the judgement of the Regional Administrative Court 
- control and measuring systems, along with a diagram representing the distribution of measuring points;

- the manner of depositing individual types of waste;

- the type and thickness of the insulating layer used;

- opening hours of a waste landfill;

- measures to prevent unauthorised persons' access to a waste landfill;

- procedures of accepting waste to a waste landfill;

- methods and frequency of testing;

- the manner of keeping documentation regarding operations of a waste landfill;

- additional requirements typical for waste landfilling;

- an emergency plan, particularly in case of detection of any change in the quality of groundwaters caused by the emissions of substances from the waste landfill.

Pursuant to article 54(1) of the Act on Waste, the closure of a waste landfill or its separated part requires a consent from the competent authority.

Upon the request from the operator of a waste landfill, by way of a decision, a consent to the closure of a waste landfill or its part is granted by a competent authority, i.e.:

- the regional director for environmental protection - for projects and incidents in closed areas;

- the marshal of a voivodeship - for projects or incidents referred to in article 378(2a) of the Act of 27 April 2001 - the Environmental Protection Act;

- the head of powiat (starosta) - for other projects ${ }^{12}$.

Before the consent to the closure of a waste landfill is granted, the waste landfill is inspected upon the request of a competent authority by the voivodeship environmental protection inspector and the representative of the competent authority. There is no need to carry out an inspection of a waste landfill, if the need for its closure results from the post-audit ordinance of the voivodeship environmental protection inspector. The consent to the closure of the waste landfill or its separated part must lay down:

12 See more on this topic in the decision of the Supreme Administrative Court (Naczelny Sąd Administracyjny) of 6 May 2010, II OW 8/10; the decision of the Supreme Administrative Court (Naczelny Sąd Administracyjny) of 14 December 2009, II OW 41/09. 


\section{Karolina Szuma}

- the technical procedure for the closure of a waste landfill or its separated part,

- the date when the waste landfill ceases to accept waste for storage at the waste landfill, which is the date of its closure;

- the schedule for actions related to reclamation of the waste landfill;

- the manner of supervision over the reclaimed waste landfill, including monitoring and the performance conditions.

An entity interested in acquisition of all the conditions arising from the decision to approve the closure of a waste landfill may submit an application to have all rights and obligations arising from the mentioned decision transferred to him. The transfer of the rights and obligations may be carried out only when the interested entity can guarantee that the obligations will be performed properly by demonstrating that they have relevant qualifications, and technical and organisational means to guarantee technical closure of the waste landfill, the performance of reclamation tasks according to the schedule, and the supervision, including monitoring, over the landfill.

The consent or refusal to transfer rights and obligations is given by way of a decision. This decision:

- produces legal effects after acquisition of a legal title to a waste landfill or its separated part;

- expires one year after it has been served, if the applicant did not receive a legal title to the waste landfill or its part.

Pursuant to article 55(1) the deposit of waste is prohibited:

- for waste in liquid form, including waste containing water in the quantity in excess of $95 \%$ of total mass, excluding sludges,

- for waste with explosive, corrosive, oxidising, highly flammable or flammable properties,

- for contagious medical and veterinary waste,

- for waste produced as a result of scientific research, development work or teaching activities the nature of which has not been identified or is new and the effects of which on humans or the environment are unknown,

- for tyres and their parts, excluding bicycle tyres and tyres with the external diameters exceeding $1,400 \mathrm{~mm}$,

- in inland surface and underground waters,

- in the Polish sea waters,

- for flammable selectively collected waste,

- in the cases set out in separate regulations. 
The dilution of waste or mixing waste with other types of waste or with other substances or objects in order to meet the criteria for waste acceptance to a waste landfill is prohibited. Waste must be deposited in a selective way. A non-selective manner of the deposit of waste (mixing) may be allowed provided that this manner of deposit does not increase the adverse effect of this waste on the environment ${ }^{13}$.

Pursuant to article 56(1) of the Act on Waste, prior to its deposit at a waste landfill, waste must be subjected to physical, chemical or biological treatment and be sorted in order to reduce danger it poses to human life and health or to the environment, or in order to reduce the quantity or volume of waste to be landfilled. The above obligations do not apply to inert waste or waste in respect of which the processes of physical, chemical or biological treatment will not reduce danger to human life and health or to the environment, or will not reduce the quantity or volume of waste to be landfilled.

Non-hazardous waste must not be deposited at hazardous waste landfills. Solid hazardous waste may be deposited in separated parts of landfills for non-hazardous and non-inert waste. Separated parts of waste landfills must meet the requirements specified for the location, construction, exploitation and closure of hazardous waste landfills. Non-hazardous waste must not be deposited at those separated parts of waste landfills ${ }^{14}$.

At non-hazardous and non-inert waste landfills the following types of waste may be deposited:

- communal waste;

- non-hazardous and non-inert waste;

- solid hazardous waste generated as a result of transformation of hazardous waste, if it meets the relevant criteria to be deposited on a non-hazardous and non-inert waste landfill ${ }^{15}$.

13 On this topic see also the Regulation of the Minister of Economy and Labour of 7 September 2005 on criteria and procedures of admissibility of waste to the given type of a waste landfill - Journal of Laws of 2005, No 186, item 1553 with amendments, and the Regulation of the Minister of Economy of 30 October 2002 on the types of waste allowed for non-selective deposition - Journal of Laws of 2002, No 191, item 1595.

14 See more on this topic W. Radecki, Komentarz do art. 57 ustawy o odpadach, electronic publishing LEX.

15 There is an interesting case which was decided by a judgement of the Court of Competition and Consumer Protection of 25 June 2003, XVII Ama 59/02 - , There are no grounds to accuse the operator of a non-hazardous and non-communal waste landfill 


\section{Karolina Szuma}

Correspondingly, only inert waste can be deposited at landfills for inert waste.

The price for the acceptance of waste at a landfill should cover, in particular, the costs of construction of the landfill, its operation, closure, reclamation, monitoring and supervision.

The legislator also provides for fines in case of unlawful acts. Thus, if an operator of a waste landfill closes the landfill or its separated part without the required consent of the competent authority, he is subject to a fine of PLN 5,000. If an operator of a waste landfill despite the decision to close the landfill continues to accept waste for deposit, he is subject to a fine of PLN 20,000.

Apart from purely theoretical deliberations, one must pay attention to a practical problem related e.g. to obtaining a permit for a waste landfill activity. Considering Polish regulations on waste landfilling, we should take into account the provisions of the Directive 2006/123/EC of the European Parliament and of the Council of 12 December 2006 on services in the internal market ${ }^{16}$. Firstly, we should express our concern regarding the fact that the provisions of the Directive 2006/123/EC are not applied in Poland, and draw attention to the same problem in other Member States, since such situation limits the rights of foreign entrepreneurs in Poland.

Here we must highlight the provisions of the Directive 2006/123/EC of the European Parliament and of the Council of 12 December 2006 on services in the internal market. Attention should be paid in particular to article 13 of the Directive and article 11 of the Act of 2 July 2004 on Freedom of Business Activity ${ }^{17}$ which implements the EU provisions.

The EU legislator in article 13(1) of the Directive 2006/123/EC requires that authorisation procedures and formalities be clear, made public in advance and be such as to provide applicants with a guarantee that their applications will be dealt with objectively and impartially. Moreover, article 13(2) of the Directive 2006/123/EC stipulates that authorisation procedures

of violating the provision of the Act of 15 December 2000 on Competition and Consumer Protection (Journal of Laws, No 122, item 1319), particularly after a refusal to accept the waste supplied by certain suppliers, if the operator of the waste landfill does not hold a dominant position on the market of non-hazardous and non-communal waste landfilling'.

16 Official Journal L 376 of 27 December 2006, p. 36-68.

17 Journal of Laws of 2010, No 220, item 1447 with amendments, further referred to as the FBA Act. 
and formalities are not dissuasive and should not unduly complicate or delay the provision of the service.

The most important thing is that authorisation procedures and formalities provide applicants with a guarantee that their application will be processed as quickly as possible and, in any event, within a reasonable period which is fixed and made public in advance. The period runs only from the time when all documentation has been submitted. When justified by the complexity of the issue, the time period may be extended once, by the competent authority, for a limited time. The extension and its duration must be duly motivated and notified to the applicant before the original period has expired (article 13(3) of the Directive 2006/123/EC). Furthermore, failing a response within the time period set or extended in accordance with paragraph 3, authorisation is deemed to have been granted. Different arrangements may nevertheless be put in place, where justified by overriding reasons relating to the public interest, including a legitimate interest of third parties (article 13(4) of the Directive 2006/123/EC).

Apart from the above, all applications for authorisation must be acknowledged as quickly as possible. The acknowledgement must specify the following:

a) the period referred to in article 13(3) of the Directive 2006/123/EC;

b) the available means of redress;

c) if applicable, a statement that in the absence of a response within the period specified, the authorisation is deemed to have been granted (article 13(5) of the Directive 2006/123/EC).

In article 11 of the FBA Act, the Polish legislator implemented the above mentioned provisions of the Directive by copying them without adjusting to the Polish legal order. Thus, Poland failed to effectively transpose the objectives laid down in the Directive into the Polish legislation.

The facts are that the EU law prevails over the national legislation of the Member States, and that the directives refer to various systems of law, and that the Member States are bound by the objectives laid down in the directives. Furthermore, the European Court of Justice allows for direct application of a directive in case a Member State is in delay in adjusting its legislation or implementing it, or does not adequately comply with the directive.

The Service Directive has been simply copied into the Polish legal system. The authorities have been obliged e.g. to notify the parties that if there is no response within the specified time period, the authorisation 


\section{Karolina Szuma}

is deemed to have been granted, and to advise the parties on available legal redress. Article 11 of the FBA Act also provides for the time period for processing the cases, as specified in the Directive.

On the other hand, no motivating measures have been provided for the authorities, who fail to comply with these obligations. Thus, the entrepreneur, who is not granted the right to which he is entitled under the Directive, has no possibility to take appropriate measures. This is the case when the authority either fails to react or even claims that the FBA Act provisions do not apply e.g. in the procedure for issuance of the permit under the Act on Waste of 27 April 2001. This distorts the meaning of the directive. Of course, a party may continue the proceedings in an administrative court, but this also contradicts the principle laid down in the Directive, i.e. that authorisation procedures and formalities provide applicants with a guarantee that their application will be processed as quickly as possible, they do not unduly complicate or delay the provision of the service.

What must be highlighted is that although the provisions of the Directive 2006/123/EC have been directly transposed into the Polish legal system, they were not given any effectiveness, and thus they are not applied by Polish administrative authorities. The provisions are officially in force, but in practice they are not applied towards entrepreneurs. The problem is that entrepreneurs are not advised on their right resulting from article 13(5) of the Directive and that procedures are not conducted with respect for the whole article 13 of the Directive.

The actual problem is the non-application of the Directive, that is departure from its provisions instead of implementation of some corrective measures.

Therefore, entrepreneurs may reasonably fear whether the principle of freedom of business activity and the free market are actually applicable in Poland. Polish and foreign entrepreneurs are thus discriminated as their business activities are being hindered. The abolition of obstacles to provide services in the Member States is a priority set out in the Treaty, with the free movement of services playing the major role. The highlighted problem weakens global competitiveness of Polish and/or foreign service providers.

Among gross negligence of Polish authorities there are numerous cases of:

- not informing that in the absence of a response within the period specified, the authorisation is deemed to have been granted (violation of article 13(5) of the Directive 2006/123/EC); 
- issuing a refusal after the time period for processing the case has expired without having extended this period (violation of article 13(3) of the Directive 2006/123/EC);

- declaring that the FBA Act provisions, which implement the Directive 2006/123/EC, do not apply e.g. in the procedure to have the permit issued pursuant to the Act on Waste of 27 April 2001 (violation of article 13 of the Directive 2006/123/EC). 